\title{
ANAPHORIC PROCESSING OF THE NULL PRONOUN IN MONOLINGUAL SPEAKERS OF BRAZILIAN PORTUGUESE: AN ONLINE STUDY
}

\author{
Rita de Cássia Freire de Melo \\ ritafmv@gmail.com \\ Federal University of Paraíba, Brazil \\ University of Pernambuco, Brazil \\ Karla Araújo Pinheiro de Holanda \\ karlaapinheiro@gmail.com \\ José Ferrari-Neto \\ joseferrarin@ibest.com.br \\ Matheus de Almeida Barbosa \\ profmatheusba@gmail.com \\ Federal University of Paraíba, Brazil
}

Received November 27, 2019; Revised December 3, 2019; Accepted December 5, 2019

\begin{abstract}
The aim of this paper was to investigate anaphoric processing of the null pronoun in Brazilian Portuguese and determine whether the perception of morphological gender features has a disambiguating effect during the process of reading. This feature enables the anaphoric null pronoun to be interpreted as referring to either the subject or object. We assume the proposal put forth by Carminati (2005) regarding the resolution of the null subject pronoun, which is based on the investigation of the processing of full and null pronouns in Italian. The sample of the present study was composed of 32 speakers of university-level Brazilian Portuguese. The stimuli were temporal adverbial subordinate clauses with the manipulation of the gender feature in the participle as disambiguating information. The authors used the self-paced reading experimental paradigm with a control response. The results were in line with that predicted by the Feature Strength Hypothesis and Antecedent Position Hypothesis put forth by Carminati (2005).

Keywords: null pronoun, monolinguals, anaphoric processing, Brazilian Portuguese, gender.

Мело Ріта, Голанда Карла, Феррарі-Нето Жозе, Барбоса Матеус де Алмейда. Анафорична обробка нульової форми займенника монолінгвами-носіями бразильського варіанта португальської: онлайн дослідження.

Анотація. Мета статті - дослідити анафоричну обробку нульової форми займенника в бразильському варіанті португальської мови та визначити, чи сприйняття гендерних морфологічних ознак має ефект розбіжності під час читання. Ця особливість дає змогу інтерпретувати анафоричну нульову форму займенника як референцію на предмет або об’єкт. Автори покликаються на гіпотезу Carminati (2005) щодо змісту нульової форми займенника, яка грунтується на дослідженні когнітивного перероблення повної та нульової форм займенників в італійській мові. Вибірку склало 32 студенти університету - носії бразильського варіанта португальської. Стимулами слугували темпоральні адвербіальні
\end{abstract}

(C) Melo, Rita de Cássia Freire de; Holanda, Karla Araújo Pinheiro de; Ferrari-Neto, José; Barbosa, Matheus de Almeida, 2019. This is an Open Access article distributed under the terms and conditions of the Creative Commons Attribution 4.0 International Licence (http://creativecommons.org/licenses/by/4.0).

East European Journal of Psycholinguistics, 6(2), 68-79. https:/doi.org/10.5281/zenodo.3637570 
підрядні речення, які змінювалися за ознакою роду дієприкметника, що знімало неоднозначність інформації. Автори використовували експериментальну платформу самоконтролю читання із контролем реакції. Результати дослідження узгоджуються 3 результатами, що передбачені гіпотезою прояву ознак (Feature Strength Hypothesis) та гіпотезою позиції антецедента (Antecedent Position Hypothesis) за термінами Carminati (2005).

Ключові слова: нульова форма займенника, монолінгви, анафорична обробка, бразильський варіант португальської, граматичний рід.

\section{Introduction}

This paper investigates anaphoric processing in monolingual speakers of Brazilian Portuguese. We seek to elucidate the anaphoric coreference that may be established through different linguistic resources, such as different types of pronouns (personal, demonstrative), the repetition of the same names for the antecedent and referent, or even by the omission of a previous term (Xavier, 2006).

Several theories approach how we comprehend and interpret anaphors considering the linguistic variety of the coreferential expressions. Besides overt pronouns, some languages also use null pronouns. These languages, however, do not always have such rich verbal inflection that provides enough information about the correct referent. Some other languages, on the other hand, have null expressions and object, despite lacking verbal morphology (Mandarin/Cantonese Chinese, for example). On this matter, linguistic findings have increased the body of research in psycholinguistics (Kaiser \& Fedele, 2019)

It is in this context that we find the notions of experimental psycholinguistics and one of the phenomena studied by this field of knowledge: coreferential processing. This type of processing regards how the human mind establishes relations between certain elements in sentences, particularly the processing of words that allude to other words in the discourse. One of the points studied in a recurrent manner has been the referential ambiguity caused by a null pronoun (pro). This ambiguity implies processing costs in the establishment of the coreference. An example taken from Carminati (2005) is given below:

\section{(1) Quando Maria chamou Mario, estava feliz.}

When Maria called Mario, pro was happy.

In this sentence, it is not possible to establish the antecedent of the null pronoun. In other words, it is not possible to state who was happy - Maria or Mario. Therefore, when the processing of a sentence like the one above reaches the null pronoun, a decision must be made regarding the establishment of the correct referent (Grosjean, 1996). When there are indications in the sentence that lead to the correct antecedent, these indications are taken into account, as occurs in the marking of gender in adjectives shown in the examples below, also extracted from Carminati (2005):

(2) Quando Maria chamou Mário, estava cansada.

When Maria called Mario, pro was tired [female adjective]. 
(3) Quando Maria chamou Mário, estava cansado.

When Maria called Mario, pro was tired [male adjective].

(4) Quando Mário chamou Pedro, estava cansado.

When Mario called Pedro, pro was tired [male adjective].

(5) Quando Maria chamou Joana, estava cansada.

When Maria called Joana, pro was tired [female adjective].

In sentences (2) and (3), disambiguation is achieved with the morphological marking of gender in the adjective at the end of the sentence. However, the antecedent can either be the subject of the sentence, as in (2), or the object of the sentence, as in (3). Moreover, there are sentences in which the antecedent could be both the subject and object, as in (4) and (5). Hence, the position of the antecedent may be a factor that influences the processing of the null pronoun, which merits investigation in an experimental study.

In several online and offline studies with data from Italian, Carminati (Carminati, 2005) found that in the retrieval of the intra-sentence anaphora with pro, individuals preferred to interpret this pronoun as having a referent introduced in the previous linguistic context in the position of subject. For example, in a self-paced reading study, reading times of the main clause were measured in sentences such as the following:

(6) Após Giovanni ter envergonhado Giorgio na frente de todos, pro se desculpou repetidamente. After Giovanni had embarrassed Giogio in front of everyone, pro apologised repeatedly.

(7) Após Giovanni ter envergonhado Giorgio na frente de todos, pro se ofendeu tremendamente. After Giovanni had embarrassed Giogio in front of everyone, pro was tremendously offended.

The results showed that the reading times of sentences such as (6) were significantly shorter than those of sentences such as (7). Thus, when the pro was pragmatically disambiguated for the previous subject rather than the previous object, the reading time was significantly reduced.

This bias to the antecedent in the position of the subject is in line with the predictions of Accessibility Theory (Ariel, 1991), which correlates the use of certain anaphoric expressions to the accessibility of mental entities that these expressions represent in one's memory. According to this theory, reduced pronominal forms, such as the unstressed pronoun in English and the null pronoun in pro-drop languages, prefer to retrieve references that are highly accessible in one's memory (Carminatti, 2005).

Anaphoric coreference has unique characteristics with regards to its processing when studying the processing of a referent by means of a phonetically null pronoun. In generative linguistic theory (Lasnik \& Lohndal, 2017), such pronouns have been characterised as one of the types of empty categories, denominated pro. Theoretical descriptions regarding this type of pronoun have very often been concerned with the 
characterisation of its distribution in the sentence (Lucchesi, 2009; Lapertua, 2004; Veríssimo, 2017) rather than the way it is processed.

Therefore, the object of the present study is the processing of coreferential relations and how the retrieval of the antecedent occurs through the pro (null pronoun) bias, considering the gender feature as a facilitator in the establishment of the correct antecedent of a referent. We assume that the Feature Strength Hypothesis and Antecedent Position Hypothesis put forth by Carminati (2005) must interact with the pronoun resolution strategies employed by the individual.

To carry out the study, we conducted a self-paced reading experiment of ambiguous sentences formed by temporal adverbial subordinate clauses with the syntactic order formed by the subordinate clause followed by the main clause containing a subject represented by a null pronoun (pro empty category) (Presuss, Finger, 2018). The choice of this sentence structure was based on studies related to the Italian language conducted by Carminati (2002). We found that the position of the antecedent in the null pronoun in Brazilian Portuguese would give results similar to those reported by the author (Carminatti, 2005).

The main objective of the present study was to investigate how the processing of the null pronoun occurs and test the feature hypothesis in monolingual speakers of Brazilian Portuguese through online processing tasks. For such, our specific objectives were to determine: i) the reading time for the referent and the critical segments; ii) linguistic factors that lead to the disambiguation of sentences based on features; and iii) whether the referent of the antecedent in the subject position is in line with the predictions of the Antecedent Position Hypothesis and Feature Strength Hypothesis (Duarte, 2015). Our intention is to understand the processing of the null pronoun in Brazilian Portuguese through an online task and contribute to the construction of a theoretical model that takes into account the role of the gender feature during processing.

In the Feature Strength Hypothesis put forth by Carminati (Carminati, 2005), morphological features code conceptual features with different degrees of cognitive meaning, making clear predictions for the processing of sentences, particularly the feature processing of pronouns. Supposing a correlation between the cognitive meaning of a gender feature (in relation to the other gender) and its power of disambiguation, the more the relevant feature, the better it will be processed in the disambiguation (Gonçalves \& Sousa, 2012).

According to Filiaci, Sorace, \& Carreiras (2014) analyzed studies about the linguistic differences between Spanish and Italian in the anaphoric interpretation of null pronoun subjects and overt pronoun subjects. The authors found in the selfpaced Reading tasks a pattern between the two languages in the resolution of anaphoric null subjects, as predicted in the Accessibility theory. The study showed, however, that, despite being closely typologically related and having morphosyntactic similarities, anaphors that seem to be equivalent in the surface of Italian and Spanish present different anaphoric preference aspects.

Gerlomini-Lezama \& Almor (2011) investigated extrasentential anaphor contexts. The research showed that with subject antecedents, sentences with overt pronouns and repeated-names were read significantly slower than sentences $\mathrm{w}$ slowly. This analysis raises a concern since the sentences from their material with 
null anaphors were systematically shorter than sentences with overt pronouns, and these were systematically shorter than sentences with names. The data also suggest some questions not raised by the authors, that, in the context, analyzed if the bias of the null subject is stronger than the bias of the subject, since reaction times seem to be higher in this condition.

However, Carminati (Carminati, 2002) based her work on accessibility theory, which retrieves the subject position for the referent, aligning with the predictions of the antecedent position (Ariel, 1990; 1994). This theory prefers to retrieve referents that are highly accessible to the memory (Carminati, 2005), in which there is a relation between the anaphoric expression and the accessibility of the antecedent.

In contrast, the Antecedent Position Hypothesis put forth by Carminati (Carminati, 2002) predicts structural relations of a syntactic basis considering the anaphoric expression and its antecedents. This theory predicts that the null pronoun in Italian occurs in intra-sentence conditions and highlights the role of the syntactic function of the antecedent, preferentially retrieving the Spec IP, which is the syntactic position occupied by the subject of the sentence.

\section{Methodological basis}

The present study consisted of an online experiment to investigate processing at the time that it occurs in the mind/brain (Leitão, 2015) and involved the use of the self-paced reading paradigm constructed and applied using the Paradigm program.

\subsection{Description of experimental design}

The purpose of the experiment described herein was to determine factors that may influence the identification of the antecedent of a referent expressed by a null pronoun. Among such factors, gender can be used to retrieve the antecedents in a sentence. Thus, the experiment described below manipulated the value of the gender feature of the antecedents (both that in the position of subject and that in the position of object).

As the structural position of the antecedent and referent are affected by their positional resemblance, the influence of this factor was also investigated. Thus, the experiment manipulated the parallelism between the antecedent and referent by controlling the gender feature in concordance between the participle and its possible antecedents. The dependent variable was the reading time of the critical segment, which corresponded to the segment in which the participle was found.

\subsection{Participants}

The sample was composed of 32 (thirty-two) monolingual speakers of Brazilian Portuguese, all of whom were students at the Federal University of Pernambuco. Age ranged from 18 (eighteen) to 51 (fifty-one) years (mean: 24.75 years). Twenty $(62.5 \%)$ of the participants were women and $12(37.5 \%)$ were men.

\subsection{Stimuli}

The experimental sentences were composed of temporal adverbial initial subordinate clauses. The distribution of the material was performed using the Latin square with a within-subjects design, which enables each participant to be exposed to all conditions and all types of structures with no repetition of the sentences. 
Eight stimuli were used per condition. We had four conditions (male/female, female/male, male/male, female/female) crossed to parallel/non-parallel positioning, forming a total of ninety-six stimuli within the proposed activity: thirty-two experimental stimuli and sixty-four distracting stimuli. The organisation of the experimental conditions was as follows:

ith null pronouns, that is, when the antecedent is an object, null sentences are read more

\section{MMP: Male - Male - Parallel}

Quando \Ivo\saia com\José pela praça\ do vilarejo,\ estava encantado\com todo $\backslash$ o intenso movimento $\backslash$ dos festejos.

When\Ivol went out with\Josél to the squarel of the village,\ pro was enchanted [male adjective] $\backslash$ with all $\backslash$ the intense movement $\backslash$ of the festivities.

\section{FFP: Female - Female - Parallel}

Quando \Lara\saia com\Pilar\ pela praça\ do vilarejo, \estava encantada\com todo $\backslash$ o intenso movimento $\backslash$ dos festejos.

When\Lara\ went out with\Pilar\ to the square enchanted [female adjective] $\backslash$ with all $\backslash$ the intense movement $\backslash$ of the festivities.

\section{MFP: Male - Female - Parallel}

Quando\José` saia com\Pilar\ pela praça\ do vilarejo, lestava encantado\com todo $\backslash$ o intenso movimento $\backslash$ dos festejos.

When\José went out with\Pilar\ to the square $\backslash$ of the village, $\backslash$ pro was enchanted [male adjective] $\backslash$ with all $\backslash$ the intense movement $\backslash$ of the festivities.

\section{FMP: Female - Male - Parallel}

Quando \Pilar\saia com\José \ela praça\ do vilarejo,\ estava encantada\com todo $\backslash$ o intenso movimento $\backslash$ dos festejos.

When\Pilar\went out with\Josél to the square\ of the village, $\backslash$ pro was enchanted [female adjective] $\backslash$ with all $\backslash$ the intense movement $\backslash$ of the festivities.

\section{MFNP: Male - Female - Non-Parallel}

Quando\José` saia com\Pilar\ pela praça\ do vilarejo, \estava encantada\ com todo $\backslash$ o intenso movimentol dos festejos.

When\José \ went out with\Pilar\ to the square enchanted [female adjective] $\backslash$ with all $\backslash$ the intense movement $\backslash$ of the festivities.

\section{FMNP: Female - Male - Non-Parallel}

Quando\Pilar\saía com\José \ela praça\ do vilarejo,\ estava encantado\com todo $\backslash \mathrm{o}$ intenso movimento $\backslash$ dos festejos.

When\Pilar\went out with\Josél to the square\ of the village, $\backslash$ pro was enchanted [male adjective $\backslash \backslash$ with all $\backslash$ the intense movement $\backslash$ of the festivities.

\section{MMNP: Male - Male - Non-Parallel}

Quando \Ivo\saia com \Josél pela praça do vilarejo, \estava encantada\com todo $\backslash \mathrm{o}$ intenso movimento $\backslash$ dos festejos. 
When \Ivo\went out with \José to the square of the village, $\backslash$ pro was enchanted [female adjective] $\backslash$ with all $\backslash$ the intense movement $\backslash$ of the festivities.

\section{FFNP: Female - Female - Non-Parallel}

Quando \Lara\saia com\Pilar\ pela praça\do vilarejo, \estava encantado\ com todo $\backslash \mathrm{o}$ intenso movimento $\backslash$ dos festejos.

When\ Lara\ went out with $\backslash$ Pilar to the square of the village, \pro was enchanted [male adjective] $\backslash$ with all $\backslash$ the intense movement $\backslash$ of the festivities.

\section{Procedure}

The task was performed in study cubicles (public libraries) to avoid outside acoustic interference and enable greater concentration. The volunteers were randomly recruited from the confines of the university at which the experiment was conducted. The task was performed on a laptop computer (Samsung Essential E22, 14", 4 GB of memory, DDR3L $1600 \mathrm{MHz}$, Intel Pentium N3540 processor with $2.16 \mathrm{GHz}$ up to $2.66 \mathrm{GHz} 2 \mathrm{MB}$ L2 Cache). Before the onset of the experiment, all volunteers signed a statement of informed consent and were assured confidentiality and anonymity.

During the experimental phase, the researcher opened the Paradigm Player software and selected the test. The participant sat in a chair in front of the laptop and was assigned a number to serve subsequently for the purposes of identification. The numbers followed a cardinal, non-redundant order.

Once the activity was initiated, instructions were given on the computer screen, after which, the volunteer was instructed to press the "space" bar to give continuity to the task. The keys were marked for abbreviation and greater temporal specificity. Although the right arrow " $>$ " had not been marked, its function was explained during the instruction phase on the initial screen, which consisted of enabling the presentation of a new word.

After the presentation of enough words to form a sentence, the participant was shown a question, for which two response options were offered. The direct answers were displayed in two rectangles: one outlined in green (on the right) and the other outline in orange (on the left) (Fig. 1).

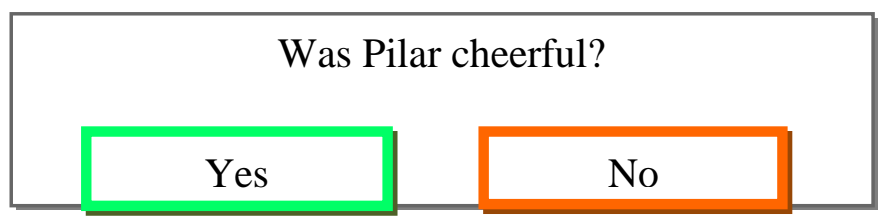

Fonte: Elaboração Própria, 2019.

Figure 1. Direct response options presented to participants after sentence was fully visualised

The intention was to enable the participant to associate what was on the computer screen with the keyboard, using keys that were positioned equally in relation to the space bar. 
During the training step, the participants were told that the researcher may intervene and what was performed during this step would be applied in the subsequent test step. The following is an example of a sentence used: "O político pediu voto aos eleitores e o juiz não gostou". "The politician asked for the vote of the electors and the judge did not like [it]."

The sentences during the training step had similar structures to those in the test step so that the subjects could become familiarised with the task to be performed. After the understanding of the instructions, the researcher withdrew from the room or cubicle and the volunteer initiated the task alone. In this phase, there was a random mixing of experimental sentences with distracting sentences.

\begin{tabular}{|c|c|}
\hline 1. & 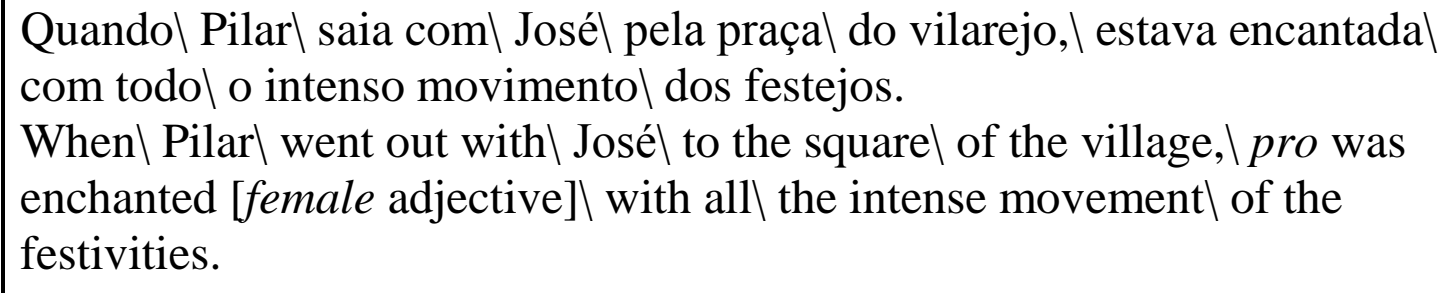 \\
\hline 2. & $\begin{array}{l}\text { Durante } \backslash \text { a tourada } \backslash \text { o touro } \backslash \text { ficou com raiva } \backslash \text { do toureiro } \backslash \text { porque } \text { este } \\
\text { mostrou } \backslash \text { uma toalha vermelha } \text { àquele com bastante } \backslash \text { determinação. } \\
\text { During } \backslash \text { the bullfight, } \backslash \text { the bull } \backslash \text { was angry } \backslash \text { at the bullfighter } \backslash \text { because } \backslash \text { he } \\
\text { showed } \backslash \text { a red cloth } \backslash \text { to it with considerable } \backslash \text { determination. }\end{array}$ \\
\hline
\end{tabular}

Figure 2. Examples of sentences used in test step

\section{Results and Discussion}

The variable of interest in the present study was the reading time of the critical segment. As the data exhibited asymmetrical (non-normal) distribution, ${ }^{1}$ the Wilcoxon test was used for the pairwise comparisons of the experimental conditions to detect whether the differences were statistically significant. The IBM Statistical Package for the Social Sciences (SPSS) was used for the statistical analysis. The results are presented in the following tables and graphs.

Table 1

Descriptive measures of reading time of critical segment

\begin{tabular}{ccccccccc}
\hline Types & MMP & FFP & MFP & FMP & MFNP & FMNP & MMNP & FFNP \\
\hline Min & 227.17 & 201.53 & 221.03 & 288.31 & 373.53 & 237.61 & 290.92 & 166.84 \\
Max & 2365.03 & 2863.11 & 3022.29 & 2935.44 & 3225.63 & 3090.43 & 4245.43 & 3943.76 \\
Mean & 998.85 & 1193.21 & 1197.05 & 1108.71 & 1221.87 & 1168.70 & 1466.52 & 1406.44 \\
SD & 459.84 & 640.22 & 625.54 & 608.16 & 725.11 & 712.73 & 903.30 & 888.99 \\
CV & $46 \%$ & $54 \%$ & $52 \%$ & $55 \%$ & $59 \%$ & $61 \%$ & $62 \%$ & $63 \%$ \\
\hline
\end{tabular}

\footnotetext{
${ }^{1}$ The normality of the data was tested using the Anderson-Darling normality test with the aid of the SPSS statistical package.
} 

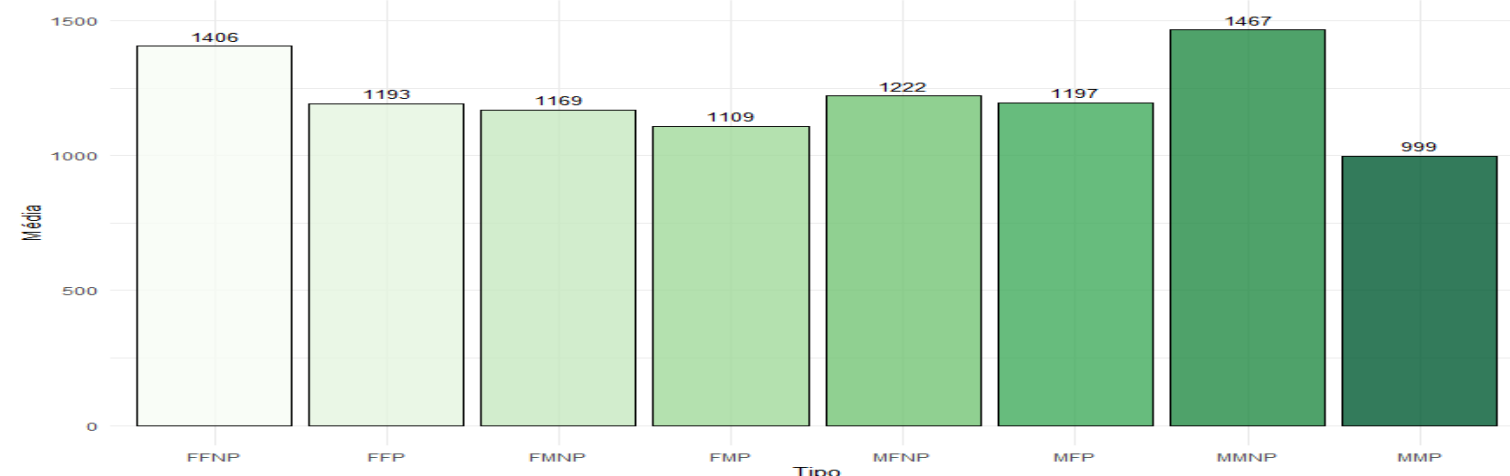

Figure 3. Distribution of mean reading time of critical segment.

Table 2

Results of the Wilcoxon test for distribution of reading time of critical segment of questions

\begin{tabular}{ccccccccc}
\hline Type & MMP & FFP & MFP & FMP & MFNP & FMNP & MMNP & FFNP \\
\hline MMP & - & .041 & .024 & .393 & .082 & .31 & 0 & .001 \\
FFP & - & - & .848 & .259 & .912 & .403 & .072 & .139 \\
MFP & - & - & - & .196 & .792 & .32 & .087 & .203 \\
FMP & - & - & - & - & .327 & .767 & .005 & .018 \\
MFNP & - & - & - & - & - & .419 & .066 & .134 \\
FMNP & - & - & - & - & - & - & .019 & .033 \\
MMNP & - & - & - & - & - & - & - & .621 \\
FFNP & - & - & - & - & - & - & - & - \\
\hline
\end{tabular}

The analysis of the experiment followed two lines of observation. The first sought to test a possible effect of the gender feature of the antecedent in both the position of subject and the position of object. Thus, the MFP condition was compared to the FMP condition, which retrieved the subject antecedents, differing only in the gender feature, MFNP was compared to FMNP, which retrieved the object antecedent, again differing only in the gender feature, MMP was compared to FFP (both conditions ambiguous with regards to the antecedent), and MMNP was compared to FFNP.

The analysis revealed significant differences only in the comparison between MMP and FFP $(\mathrm{p}<.041)$. As shown in Table 1 , the reaction times for male antecedents were shorter compared to those for female antecedents, suggesting that the male gender feature has a lower processing cost than the female feature. In this case, the degree of assertiveness stems from the Feature Strength Hypothesis (Carminati, 2005). No significant differences were found in the comparison of the other conditions.

The second analysis was performed to determine the influence of parallelism. For such, the following conditions were compared: MFP to MFNP, FMP to FMNP, which have male and female genders but differ only with regards to the referent 
element (at times subject and at times object), MMP to MMNP and FFP to FFNP. The effect was only significant for the MMP-MMNP comparison. As there is a comparison between a grammatical (MMP) and ungrammatical (MMNP) condition in this case, the difference cannot be attributed to parallelism - the ungrammatical aspect appears to be the overriding factor.

Curiously, the same did not occur in the comparison between the FFP and FFNP conditions, which may be attributed to the difference in the male and female features with regards to the online processing cost. The Feature Strength Hypothesis put forth by Carminati (Carminati, 2005) shows that processing is abandoned and respectively disambiguated when the feature has greater relevance to the individual. In this case, significance seems to be greater on behalf of the female gender.

The other statistical differences regarded the comparison between the MMNP and FFNP conditions and the other conditions. In the comparison of the experimental conditions to the MMNP condition, significant differences emerged or tended to emerge, as they approached the level of significance. However, the same pattern was not found for the comparisons to the FFNP condition, which tended not to present significant differences. This seems to indicate a difference between male and female features: the ungrammaticality motivated by the male trait tended to be less costly than that of its female counterpart. This result may also be explained by the Feature Strength Hypothesis (Carminati, 2005). In other words, the male gender may be expressed in both the degree of significance and neutrality in a sentence, whether it is grammatical or not, making the processing faster, and may equally be made in relation to any antecedent gender.

\section{Conclusions}

The results of the present study point to the Feature Strength Hypothesis (Carminati, 2005), underscoring the importance of gender marking to the disambiguation of the reader's interpretation. The effect of disambiguation was clearer in cases of the marking of the female gender. This is because the referent was ambiguated in adjectives marked by the male gender and could refer to both the object and subject, as the adjective expressed neutrality.

In cases of adjectives marked by the female gender, the referents had extremely long reading times, demonstrating a greater processing cost and a clear perception on the part of the reader with regards to the ungrammaticality of the sentence. The same hypothesis (Carminati, 2005) was also a facilitating axis in the online experimental processing.

In summary, the gender feature is relevant information to the processing of null pronouns, especially with regards to interpretation, and is therefore a linguistic factor that leads to the disambiguation of sentences. This is in line with the prediction of the Feature Strength Hypothesis, which states that grammatical features, such as gender and number, can serve as relevant elements for anaphoric processing, especially in situations in which this processing occurs in sentences with some type of ambiguity generated by the coreferential element. 
In contrast, the position of the antecedent was not found to be relevant to processing or the attribution of the interpretation, which is not in line with the Antecedent Position Hypothesis. Therefore, further data and analyses are required before this hypothesis can be evidenced with experimental data, such as those obtained herein.

In the present experiment, we investigated the response times to the control question, taken as an indication of the degree of difficulty imposed by null pronouns to their interpretation. We also counted the responses given to the same question, considering these responses as being suggestive of the interpretation of null pronouns on the part of the volunteers. However, these analyses have not yet been submitted to statistical treatment and were therefore not presented in this paper. We believe that these data will provide evidence in the direction of the initial data described and analysed herein, contributing further to the discussion on the Feature Strength and Antecedent Position hypotheses.

The present study was conducted to understand the processing of the null pronoun in Brazilian Portuguese through an online task and presented a set of data demonstrating the role of the gender featuring during processing. The continuation of the research outlined here will deepen the investigation in this field not only by extending the analysis to novel data, but by testing factors that may exert an influence on the processing of null pronouns, such as crosslinguistic differences and the effects of bilingualism.

\section{References}

Ariel, M. (1991). The function of accessibility in a theory of grammar. Journal of Pragmatics, 16(5), 443-463. doi: 10.1016/0378-2166(91)90136-L

Carminati, M. N. (2002). The processing of Italian subject pronouns. Dissertação de doutoramento, University of Massachusetts at Amherst, Amherst, MA: GLSA Publications.

Carminati, M. N. (2005). Processing reflexes of the Feature Hierarchy (Person > Number > Gender) and implications for linguistic theory. Lingua, 115, 259-285. doi: 10.1016/j.lingua.2003.10.006

Lasnik, H. \& Lohndal, T. (2017). Noam Chomsky. In Oxford Research Encyclopedia of Linguistics. doi: 10.1093/acrefore/9780199384655.013.356

Duarte, M. E. L. (2015) A perda do princípio "Evite Pronome" no Português Brasileiro. Campinas, SP: EDUNICAMP.

Filiacia, F. Soracea, A., Carreiras M. (2013). Anaphoric biases of null and overt subjects in Italian and Spanish: a cross-linguistic comparison. Language, Cognition and Neuroscience, 29(7), 825-843. doi: 10.1080/01690965.2013.801502

Gelormini-Lezama, C., Almor, A. (2011). Repeated names, overt pronouns, and null pronouns in Spanish, Language and Cognitive Processes, 26(3), 437-454. doi: 10.1080/01690965.2010.495234

Gonçalves, A. V. G., Sousa, M. L. (2012). Ciências Da Linguagem: O Fazer Cientifico?. (1st Ed.). São Paulo, SP. Editora Mercado de letras.

Grosjean, F. (1996). Living with two languages and two cultures. In I. Parasnis, Ed. Cultural and language diversity and the deaf experience. (pp. 20-37) Cambridge: Cambridge University Press. 
Kaiser, E., Fedele, E. (2019). Reference resolution: a psycholinguistic perspective. J. Gundel \& B. Abbott, (Eds.). The Oxford Handbook of Reference. doi: 10.1093/oxfordhb/9780199687305.013.15

Lapertua, M. (2004) Sujeito nulo na aquisição: um parâmetro em mudança - sujeito preenchido na aprendizagem: a eterna tentativa de mudança. Revista do Gelne, 6(1), 141.

Limberger, B., Buchweitz, A. (2012). Estudos sobre a relação entre bilinguismo e cognição: o controle inibitório e a memória de trabalho. Letrônica, 5(3), 67-87,

Lucchesi, D. (2009). A realização do sujeito pronominal. In D. Lucchesi, A. Baxter, \& I. Ribeiro, (Eds.). O português afro-brasileiro (pp. 165-183). Salvador, BA: EDUFBA.

Presuss, E. O., Finger, I. F. (2018). A dinâmica do Processamento Bilíngue. Campinas, SP. Pontes Editoras.

Veríssimo, V. (2017). A evolução do conceito de parâmetro do sujeito nulo. Entrepalavras, Fortaleza, 7, 76-90.

Xavier, G. R. (2006). Português Brasileiro como Segunda Língua: Um Estudo sobre o Sujeito Nulo. Campinas, SP: EDUNICAMP. 